\title{
The Pushing Forces to the Formation of Ethnic-based Political Parties Ethiopia in the Post 1991
}

\author{
Getnet Addisu Gelaneh \\ Department of Political Science \& International Relations, College of Social Science and Humanities, Jigjiga University, Jigjiga, Ethiopia
}

\section{Email address:}

getentaddisu2@gmail.com

\section{To cite this article:}

Getnet Addisu Gelaneh. The Pushing Forces to the Formation of Ethnic-based Political Parties Ethiopia in the Post 1991. Journal of Political Science and International Relations. Vol. 3, No. 4, 2020, pp. 97-102. doi: 10.11648/j.jpsir.20200304.11

Received: September 30, 2020; Accepted: October 19, 2020; Published: October 26, 2020

\begin{abstract}
The aim of the paper is intended to look into the driving forces to the formation of Ethnic-based political parties Ethiopia in post 1991. To address the objectives of the study, the researcher employed qualitative approach with case study as study design and used primary and secondary data sources. Primary data collected from the key informant interview and FGDs. Secondary data collected from different books, reports, journals, published and unpublished proclamations, conference papers, dissertations and Federal Democratic Republic of Ethiopia (FDRE) constitution. The researcher used purposive sampling and thematic analysis method based on the objectives of the study. The study findings indicated that With the view of ensuring unity with diversity the finding of the study has revealed that ethnic-based political parties emerged in Ethiopia with: the contradictory political debates on history, the nature of the constitution, exploitation and the divide and rule political program of Tigray Peoples Liberation Front (TPLF) contributed a lot to the existing ethnic-based politics in Ethiopia.
\end{abstract}

Keywords: Ethnicity, Politics, Ethnic Politics, Ethiopia

\section{Introduction}

The Ethiopian People's Revolutionary Democratic Front (EPRDF) a coalition of four ethnically and regionally representative parties came to power in Ethiopia in 1991 after overthrow the Derg, the military junta that had ruled since 1974. The factors that throw in to the formation of these political parties based on the response of the participants and article analysis by using the criteria's which used to measure the factors of the ethnic political parties organized. The criteria's which used to assess the forces that contributes the formation of ethnic political parties include; the contradictory interpretation of national oppression thesis by the political elites, the nature of the federal structure and the constitution, deprivation and exploitation and the TPLF divide rule political program has discussed under this study.

Contradictory Interpretation of Ethiopian History by the Political Elites

Under the Ethiopian political history; there are polarized political disagreements on the national oppression discourse. From this as the data shown that the nation-building process of Ethiopia is similar to the other world states emerged, i.e., through forceful suppression and peaceful. But the mistaken narratives has been narrated by the Ethiopian regimes were in addressing the nationality questions. They were neither democratic enough nor authoritarian in making of Ethiopian one in all aspects. Our regimes thought us different narratives about the nation building of Ethiopia. Some state builders of the modern Ethiopian state, such as Emperor Menelik II, for example, are viewed as heroes by some identities while others view him as brutal colonizer. This event made us in holding different insights towards our history. Concomitantly, as scholars argued that Ethiopian history, like the history of all state-building, is partly a history of fighting, conquest and dominance. Since the way we perceive historical events influences our political consciousness, the way we relate to these historical wounds has significance for the present. It is then crucial that Ethiopian political theory reflect on the political meanings and implications of historical wounds for the present and the future.

At the same token, the data confirmed that history by itself is not a problem; it turns into a problem when it is not accommodated or manipulated by opportunistic politicians. The state understands Ethiopian history in politically, they believed and wrote Ethiopia is only the history of some ethnic groups. Therefore, our problem on our history and the 
ethnic politics is in historiography. That means when a given ethnic group holds the power he/she tried to advocate not to all Ethiopia's rather to their ethnic group only. Therefore, we have a problem on oppression thesis. As we have agreed that the prevalence of different political parties in Ethiopia; however, still now we are not interested to accept the prevalence of diverse perception and narrative about our history. This becomes the force that initiates the political elites to the formation of ethnic-based political system in Ethiopia.

Likewise, Tareke [14] found that not recognizing surplushistory leads to the two interrelated problems current Ethiopian political thinking: nation-centrism and ethnocentrism. Nationalist discourse forgets that Ethiopia is a composite nation forged the multifarious processes of integration and disintegration, and depicts as a nation that has come on the historical scene fully formed.

Concomitantly, there are contradictory interpretations of Ethiopian history. We agreed differently, for example when the given ethnic group came to power thoughts; the predecessors' regimes of Ethiopia were autocrat enough in suppressing other ethnic groups. Therefore, based on the above data the researcher has investigated that the EPRDF government of Ethiopia has been creating a narration about the different leaders Ethiopia as brutal and EPRDF as the only democratic. This leads us to hold different perception about our history. Regarding Ethiopia, it is evident that its history of ethnicity, ethnic relations and evolution of the state by itself is subject to polarized debates. However, everyone agrees that Ethiopia hosts a plurality of ethnic groups. Thus, disagreement is over whether or not ethnic differences and relations had been problematic in Ethiopian history that seeks a new political order.

As a counter balance, after the adoption of ethnic-based federal structure in Ethiopia the central government tried to expand ethnic political debates on Ethiopian history. As Merera Gudina [9] found that central to the current crisis of the Ethiopian State is ethnic nationalism, which easily gives rise to multiple competing interests, contradictory visions and clashes of dreams especially among the contending elites who are the moving spirit of ethnic nationalism. For instance, the hegemonic aspiration of the Tigrean elite, the reminiscence for the imperial days by part of the Amhara elite and the dream to create independent Oromia by part of the Oromo elite are excellent examples of the contradictory demands on the Ethiopian state. On other hand, the focus group discussant also argued: In the previous years of Ethiopian history, the Oromo political elites were had been written with different international journals, they wrote and agreed with one narrative, "the Oromo peoples question is a question of colonization" what they call it "colonial thesis theory". The central message of this false narrative is "in 19 the the Oromo peoples were defeated by Amharas". They believed that this narrative leads and expands throughout the world the Amharas are colonizer in Ethiopia, like the French and British rulers in Africa.

Generally, it is plausible to agree that Ethiopia history is a point of disagreement among different political elites. As the study shown that the polarized political debate on the past Ethiopian history leads to the realization of many ethnicbased political parties and some ethnic group believed that as the oppressed and others as oppressor. As the informants argued that this thesis and antithesis discourse brings a huge obstacle to the civic oriented political parties run to hold the political power. The same with that the scholars argued that the current political impasse in Ethiopia reflects these two radically opposed appropriations of the past. The EPRDF ignores the historical present and its new characteristics and reads Ethiopian history and politics as a recollection of past injustices that could be rectified only through the creation of ethnicstans and the articulation and distribution of power through electoral substitutionalism.

\section{The Nature of the Ethiopian Ethnic-Based Federal Structure \& Constitution}

Ethiopian ethnic-based federal system explains the equality of nation, nationality, and peoples. Accordingly, the legal experts said that "EPRDF amended the identity-based federal structure by restructuring the constitution and not to answer the question of nationalities including selfdetermination up to secession. Rather this leads us to disintegration and the formation of ethnic based political parties". At the same token, these constitutional rights are not respected in practically. Ethnic federalism is initiated in Ethiopia on the basis of polarizing ethnic identity markers by discrediting commonalities. This created the notion of "we" and "them" category that resulted in unhealthy competition and ethnic-based politics. The constitution has been given protection to some ethnic groups to the right to selfdetermination and others are not. We can see the Sidama, Wolayita as well as the Kaffa ethnic groups' selfdetermination and the question of to be an autonomous region in Ethiopia. But the partisan government did not allow to them, even if they fulfilled the criteria's which stated in the constitution. Nevertheless, the Harari peoples are now autonomous region, when we compare with the above ethnic groups; these are beyond the stated criteria than Harari. This tells us how much the Ethiopian ethnic federal system is exploited by the leading government and discriminated the questions of ethnic groups at the national level. And this generates a favorable environment for the appearance of many ethnic based groups in Ethiopia.

Similarly, the Ethiopian ethnic-based federal structure, in 1991, "the relative change of national identity and the subsequent revision of Ethiopia's history at the beginning of the 1990s appeared more controversial than the implementation of the federal system itself" [15]. In fact, multinational federalism was strongly condemned by observers for being the "denial" of "Ethiopianist feeling" supposedly born in Adwa, putting at risk national unity [16] and eventually leading to the "country's disintegration" [8]. 
Very early, political movements defending Ethiopia's unity expressed their concern about the ethnic divisions Ethiopia would be facing [7].

Furthermore, the Ethiopian federal system is structured based on language and ethnicity. This ethnic-based federal system created the unhealthy relationship among ethnic groups in the economy, politics, culture, and history. Our conflicts are now happing because the constitution allows ethnic identity is above Ethiopian nationalism and sovereignty was not exercised in the Ethiopian people but among the nations, nationalities and peoples; there are unhealthy competitions among the ethnic groups. The ethnic conflicts Ethiopia is created by the language and ethnic based federal structure of the state rather than the ordinary citizens of Ethiopia. The causes of ethnic based eviction and displacements are committed because of our ethnic-based federal structure. And this created different ethnic-based political parties. Likewise, the Ethiopian constitution (FDRE, 47) found that "States shall be delimited on the basis of the settlement patterns, language, identity and consent of the peoples concerned" (Art, 47-2).

In the same manner, according to the constitution the regional and local governments are not autonomous in the handling of their matters based on their respective boundaries. We have been heard that the central government has the power to intervene in all aspects of ethnic matters even if to the deconstruction of regions. However, this is dangerous that could disintegrate the country. The constitution has given high emphasis to ethnic values than the common sense of nationalism. On the other hand, in every administrative boundary the constitution should allow autonomous right to self-administration; but, many laws are now made by the federal government. This brings huge questions among the nationalities to the formation of ethnic based political parties in Ethiopia.

As some educators argued, the ethnic based model of Ethiopian federal structure, this arrangement is criticized for its fictitious ethnic coalition organizations which have formed EPRDF [10]. As observed by Marina Ottaway [11] as far back as 1995, EPRDF's practices are characterized by mere emphasis on democratization and federalism as purely formal processes without contents. Hence, under the prevailing conditions in Ethiopia, one cannot talk about federalist decentralization of power. However, in theoretically speaking, the consociational and centripetalist approaches are tend to concentrate on the design or reform of democratic institutions that mediate between state and society, such as political parties and party systems; on institutions which determine how these parties and groups will be represented, particularly the electoral system; and (in part as a consequence of the interaction of party and electoral engineering) on the composition of inclusive cabinets and executive governments [13].

Furthermore, the Ethiopian constitutional amendment is highly unconstitutional which denies the powers of the judiciaries to interpret the constitution impartially rather the HoF cannot be by any means independent in interpreting it.
This contributed to the ethnic-based parties are emerged. The Ethiopian Constitution denies regular courts the power either of interpreting constitutional provisions or of reviewing the constitutionality of legislations. The constitutional framers viewed the judiciary as undemocratic and conservative. They also believed that constitutional adjudication is a political function. This fear of judicial activism and the political question doctrine persuaded the framers to deny courts the power of judicial review. Constitutional amendment is more of a political process than ordinary legislation making. Therefore, neither HoF nor courts may review the constitutionality of amendments under the Ethiopian legal system. The system lacks an appropriate institution to rule on un-constitutional constitutional amendments, which undermines the Constitution [17].

By hook or by crook, as the study confirmed that the ethnic federal structure of Ethiopia is accountable to the existing ethnic based political parties; because the constitution exists in a framework by focusing on Ethiopian politics where ethnicity has been widely politicized over the last years by the Tigray-based ruling party EPRDF. The federal system and the constitution were served on to the interest of the ruling party. And the ethnic-based federal structure by its nature exposed to ethnic politics. In this regard the nation integration process becomes a dream to the peoples who wants to see a sense of Ethiopinismrather; this huge problem contributes to the emergence of ethnically based parties in significantly. Theoretically, if the same party organization controls the federal and regional governments and has a centralized party structure, this is likely to weaken the power of regional governments and undermine regional autonomy [1].

\section{Exploitation and Domination}

The suppression of the Oromo ethnic group as ethnic plan and development in Ethiopia. The one is subsequent plans declared by the government in 2014 to largely expand Addis Ababa "the Addis Ababa Master plan", which would have seemingly incorporated around 30 towns and villages in the Oromia region and transferred thousands of farmers from their land without satisfactory payment. In general, the marginalization and their protest in the previous years was an expression of this problem. Additionally, while it may be possible right now, it cannot be ruled out that future generations will give it a serious thought, contour and even form. The lost generation during the last year's wars, who were roaming the streets in most parts of Ethiopia. While Oromo experience some state and societal discrimination on the basis of ethnicity, it is not, on its own, sufficiently serious by its nature and repetition as to constitute harassment or serious harm.

At the same token, according to AsafaJalata [3] found that the Tigrayan regime tried to implement the so-called Addis Ababa Master Plan that the Oromo called "the Master Genocide" in 2014, and the Oromo in general and the Oromo students in particular peacefully resisted this genocidal policy 
that was intended to totally uproot Oromo farmers around the capital city and transfer their lands to Tigrayans and supporters. The regime killed or imprisoned Oromo students and others who opposed the so-called the Addis Ababa Master Plan. Almost all Oromo students have opposed this plan and peacefully demonstrated all over Oromia.

On the other hand, the forces that contributed ethnic mobilization in our country is, before the coming of TPLF/ EPRDF into as many people's argued there were power dilemmas the central government of Ethiopia dominated by the autocrats with a long period of time. This becoming develop a sense of reciprocity in Ethiopia when a given political party came to in position, the Ethiopian people's firstly ask the question from which ethnic group the political parties have taken the power? Anyone can easily understand what is happening now in Ethiopia. Business and industry in Ethiopia were dominated by Tigray. All important government positions were controlled by Tigrigna speaking due to their better professional experiences. This created a cause for the emergence of ethnic politics in the different ethnic groups in Ethiopia. And Tigray people \& their political leaders felt their existence in threat, and many ethnic groups organizing themselves.

As it was depicted in the above, however, in the Ethiopian ethnic-based federal structure, the available data on regional allocation from government-controlled sources demonstrates the uneven distribution of national resources. The Tigray region's per capita share of the federal subsidy is consistently higher than Oromia, Amhara and SNNP regions, which constitute more than $80 \%$ of the country's population. The same is true for capital expenditures per capita as well as foreign loans and aid per capita. The capital expenditure per capita for Tigray is two to three times greater than Oromia [9]. Here the above information indicates that the ruling party has misuse of the national resources of the country.

In the same manner, based on study the driving force of ethnic mobilization in Ethiopia is especially the EPRDF government undefined political program mobilizes ethnic politics in Ethiopia. The government used the questions of equality of nationalities' for his political passport. He is neither revolutionary nor democratic. The government has been announced the "revolutionary democracy" it was the mother of all problems that were happened in Ethiopia. The government to extending his power through tried to establish the protectorate and pseudo-political parties in different regions of Ethiopia. In Amhara region ANDM in Oromia OPDO and SNNPR, SEPDM. These political parties were fake and autocrat in their respective regions rather they have been served to achieve the objective and the missions of TPLF. The above mentioned problems implemented by the regimes are the pushing factors for the emergence of ethnic political parties in Ethiopia. Concomitant to this, Ethiopia was wracked with disastrous political and economic crises. In 1991, the victorious Tigrean People's Liberation Front (TPLF) organized Ethiopia into a federation of ethnicstans which is ruled under the cover of a coalition of ethnic parties of its creation? The Ethiopian People's Revolutionary Democratic
Front [8].

The data which is obtained that different political parties have existed in the in our country that Ethiopian people's have been faced with patterns of exclusion, rejection, privilege, discrimination, and violence by the government. However, as they raised there have been any political party and ethnic groups publically stands for ethnic discrimination and exclusion. And most of the ethnic groups of Ethiopia were excluded in terms of economy, political and empowerment of their peoples. Therefore, they argued that if there is ethnic politics in Ethiopia, it opens a chance to these multiethnic societies for the development of their politics and economy. Their intention is Ethnic groups can lead by their respective elites.

As Quadir, [12] confirmed that if a region or group feels rightly or wrongly, that it is exploited or dominated or oppressed by other regions or groups or by the central government, it becomes more and more conscious of ethnic differences, and increasingly resorts to violence and agitational politics. For example, the then East Pakistanis, i.e., Bengalis in the pre-1971 period strongly felt that they did not have equal share in the authoritative decision making process at the center, and that there were both political and economic exploitation, domination and oppression, etc., of the eastern wing by the western wing. Although the former earned much more foreign exchange than the latter, much less was spent for the development of the former [12].

As it was learnt from the above, the prevalence of exploitation in Ethiopia. They have focused on how much the Ethiopian people's experienced injustice and inequality. The Ethiopian people did not have proportionate representation in political life and face restrictions on the political representations. This has been resulted in discrimination as well as political and socio-economic marginalization which were committed by different governments. Therefore, we can generalize that, thus, it can be plausible to assert that the rise of ethnic solidarity in Ethiopia is not because of primordial tendencies but rather because of the social and historical factors of suppression [5].

\section{The Divide and Rule Political Program of TPLF}

In this regard the study has shown that:

Our political party is formed in recently not more than a year, as we all know the Amhara peoples were contribute a lot to the formation and development of Ethiopia in many aspects, as well as for our independence. However, he had played a great role, many regimes were discriminated this people, by forceful displacement and eviction from many parts of the country, particularly with the past 27 years. The federal government tried to harass how much the Amhara rulers were autocrat for the rest of Ethiopian people's particularly by creating fake narratives to the Amhara peoples as enemy for Oromia peoples, like the construction of Anoole memorial monument, which is identity 
representation fallacy committed by the TPLF regime in post 1991.

The above speech is similar with Abbink [2], the confrontation and latent conflict between the two dominant ethnic groups, Amhara and Oromo was add Benzene over inflame by the ruling party to sustain the domination of minority-TPLF over others via implementing divide and rule tactics. The ruling party-reads unwritten history politically manipulates hostile relations that happened so far to escalate up conflicts between Amhara and Oromo to weaken the unity of the two so that it reduces potential challengers of the party. The same with that key informant interview respondent 010 from the political elites reveals that after the TPLF came to power in Ethiopia in 1991 tried to publicize his propaganda relentlessly and the political marginalization for those who refuse to play this game so serious, that some Ethiopian nationalists decided to organize as Amharas to participate in the political process. They have been created pseudo narratives and frustration among ethnic groups rather they did not construct strong and essential democratic institutions. Even if they have been said the monuments of Axum is not the concern of Wolayita and soon. This was their divide and rule ideology to the destruction of national feelings.

Much like, due to the fake narratives have been committed in our country by the leading government. The Amhara peoples have to displace and discriminated against the central government and decrease the federal budget by hiding the exact population number of Amhara especially with the previous national censuses in Ethiopia, this brings poverty and lack of mega projects in this region. Therefore, in order to defend our basic problems and to bring equal distribution of resources, budget, power we are organized our political party with ethnic lines. However, when organized in terms of ethnic line, not too discriminating the other first we hold Amhara peoples and we bring unity and national sentiment in Ethiopia.

In the same manner, as the 2007 census result for the Amhara region is not consistent with current demographic and development trends. Since the census (in 1994), there has not been famine, war, communicable disease or natural disaster that caused high rate of morality in the Amhara region. These factors would have been important if the census was carried out in the 1970s and 1980s when disease, war and famine caused the death of millions of people in Northern Ethiopia. In fact, the post-1994 period has seen an expansion of public services to rural areas which means that life expectancy for children and adults has improved. Then, has the Amhara region reached Stage Three of the demographic transition? Not. Did people move? They might have left for other regions and abroad, but their numbers cannot be statistically significant (too low). He rose that the data here provides no explanation as to why fertility has declined in the Amhara region, and not in other regions, since 1994. The Amhara region is an exception, with data showing an increase in fertility of only $24 \%$, compared with $40 \%$ for Affar, $45 \%$ for Oromiya, 44\% for SNNP, $87 \%$ for Gambella, $45 \%$ for Benishangul-Gumuz and $29 \%$ for Somali, or, surprisingly, less than the fertility rate of a metropolitan city Addis Ababa (28\%) [6].

Generally, based on this the marginalization of the many ethnic groups by the central government in different aspects, in pseudo narratives, to extending the political powers of the regime. The EPRDF regime did a lot to the destruction and divisions of ethnic groups. The regime has been fabricated pseudo narrative to marginalize many ethnic groups in economically, politically, socially as well as culturally. Therefore, this narrative mobilizes ethnic nationalism and ethnic politics in Ethiopia.

In sum, there are various forces that motivate the formation of ethnic political parties in Ethiopia. The contradictory interpretation of history the political elites miss agreement on the nation building process of Ethiopia, the nature of the existing constitution, deprivation and the TPLF divide and rule political program has been aggravated to the formation of ethic politics in Ethiopia. The promises of ethnic federalism were short-lived, and soon betrayed TPLF's "divide and rule" strategy [9] aiming at securing Tigreans' political supremacy resulting notably in a pro-Tigrean public good allocation due to an excessive financial dependence of the federal regions on the central government.

\section{Conclusions}

The main objective of this study was to investigate the driving forces to the formation of ethnic-based political parties in Ethiopia in post 1991. The study has shown that Ethiopia's pluralistic nature has made her subject to multiethnic political parties arise from the pursuit of contradictory interest. The study assessed based on the parameters including; contradictory interpretation of national oppression discourse, the federal nature of the state, exploitation and the TPLF divide and political program. Accordingly, the finding of the study reveals that the point of disagreement among different political elites opens a chance to the formation of ethnic political parties in Ethiopia. The political elites argued on polarized political debates on the history of the nationbuilding process of Ethiopia, considered a thesis on one ethnic group as oppressor and the others as oppressed contributed a lot to the current ethnic-based political parties existed. In line with as the study confirmed that, after Ethiopia adopted ethnic- based government structure, the federal system considered as a political tool the EPRDF government served to brings grievances and the ethnic groups formed their own identity based political party. Through generations, the questions of equality were remained unsolved and the exploitation of ethnic groups is also one driving force to the coming of the current ethnicbased political parties

\section{Recommendations}

"A house divided against itself cannot stand. I believe this government cannot endure permanently half slave and half free". Abraham Lincoln. 
After a significant investigation of how ethnic-based politics have emerged in Ethiopia, since the foundation of Ethiopia as a federalist nation, it therefore becomes relevant to make helpful recommendations.

We have to extend our support to national institutions and national political parties while discouraging the regional ones. Unlike history, we have to ensure the political participation of every citizen so that no one felt excluded and the common national identity could develop.

The concerned stakeholders should conduct continues open-ended dialogue like the political elites, civil societies, political party leaders as well as professional association leaders, in the national integration of Ethiopia.

The government of Ethiopia should work for national integration, social cohesion, harmony and ensure legal political competition in the country. In this regard, the government should ensure the supremacy of democracy and rule of law among the ethnic groups.

The government should work to remove all ethnic unhealthy competitions' which challenging the overall integration and consensus of the country. These include political intolerance, ethnic discrimination, and aggravation among ethnic groups.

\section{References}

[1] Aalen, L. (2002). Ethnic Federalism in a Dominant Party State: the Ethiopian Experience1991- 2000. Norway: Michelsen Institute.

[2] Abbink, J. (1997). Ethnicity and Constitutionalism in Contemporary Ethiopia. Journal of African Law, 41 (2), 159174.

[3] Asafa Jalata (2016). The Oromo National Movement and Gross Human Rights Violations in the Age of Globalization. European Scientific Journal, 12 (5), 186-197.

[4] Belachew Gebrewold (2009). Ethiopian Nationalism: an Ideology to Transcend All Odds, in Africa Spectrum. Institute of African Affairs, 44 (1), 79-97.
[5] Birhanu Gutama (2008). Ethnicity and Restructuring of the State in Ethiopia. International and Social Studies, (6), 3-27.

[6] Getachew Mequanent (2008). The 2007 Population Census in the Amhara Region Is Underreported, 1-7.

[7] Levine, D. M. (1992). Meles Zenawi and the Politics of Ethnicity: Ethiopian Review, 2 (9), 1417.

[8] Maimire, M. (2005). Ethiopian history and critical theory: The case of Adwa. The battle of Adwa. Reflexions on Ethiopia's historic victory against European colonialism, 253-301.

[9] Merera Gudina (2002). Ethiopia: Transition without Democratization. (PhD Thesis: Addis Ababa University).

[10] Muhabie Mekonnen (2015). Ethnic Federalism: A Means for Managing or a Triggering Factor for Ethnic Conflicts in Ethiopia? International journal of political science development, 3 (9), 386-399.

[11] Ottway, M. (1995). The Ethiopian Transition: Democratization or New Authoritarianism. Northeast African Studies, 2 (3), 6787.

[12] Quadir, M. Z., \& Duggan, B. J. (2004). Deformation banding and recrystallization of $\alpha$ fibre components in heavily rolled IF steel. Actamaterialia, 52 (13), 4011-4021.

[13] Reilly, B. (2006). Democracy and Diversity: Political Engineering in the Asia-Pacific. New York: Oxford University Press.

[14] Tareke Gebru (1991). Ethiopia: Power and Protest: peasant revolts in the twentieth century. New York: Cambridge University Press.

[15] Tronvoll, K. (2009). War \& the Politics of Identity in Ethiopia. The Making of Enemies \& Allies in the Horn of Africa. Eastern Africa series London: James Currey.

[16] Worku (1993, October). The Regionalization Controversy: Ethiopian Government's Policy of Privatization Opposed by Ethnic Groups, Africa Report.

[17] Zelalem Eshetu (2015). Unconstitutional Constitutional Amendments in Ethiopia. Haramaya Law Review, 4 (1), 77-87. 